\title{
COMPOSITE CU-Cr MATERIALS UNDER THERMAL ACTION OF ELECTRIC ARC DISCHARGE PLASMA
}

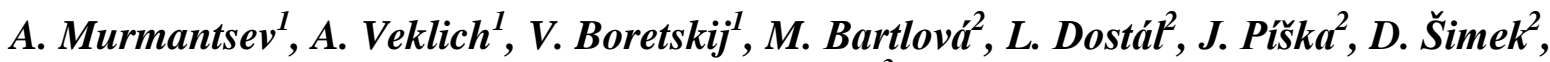 \\ A. Tolochyn ${ }^{3}$ \\ ${ }^{1}$ Taras Shevchenko National University of Kyiv, Kyiv, Ukraine; \\ ${ }^{2}$ Brno University of Technology, Brno, Czech Republic; \\ ${ }^{3}$ Frantsevich Institute for Problems of Materials Science NAS of Ukraine, Kyiv, Ukraine \\ E-mail: murmantsev.aleksandr@gmail.com
}

\begin{abstract}
The results of optical emission spectroscopy (OES) investigation of plasma of electric arc discharges in steadystate mode between $\mathrm{Cu}-\mathrm{Cr}$ composite electrodes, manufactured at different sintered temperatures: 750, 850, 950 or $1050{ }^{\circ} \mathrm{C}$, is presented. In particular, the impact of sintering temperature on erosion resistanceof such composite materials, which was determined in indirect manner by estimation of metal vapours content in the midsection of discharge gaps, is studied by the analysis of plasma parameters. These contents were calculated in assumption of local thermodynamic equilibrium (LTE) on the base of experimentally obtained radial distributions of plasma temperature and electron density.
\end{abstract}

PACS: 52.70.-m, 52.80.Mg

\section{INTRODUCTION}

Over the last few decades, composite materials have become widely used due to the specific advantages that have arisen due to the various useful properties of such materials individual components [1]. Specifically, the composites, such as $\mathrm{Cu}-\mathrm{Cr}$, are of great interest in the electric power industry [2], electrical discharge machining [3, 4], electrical railway system [5] etc.This interest is explained by numerous excellent properties of the $\mathrm{Cu}-\mathrm{Cr}$ materials, which are important for such branches of industry. First of all, it is high thermal and electrical conductivity, provided by copper component, and the second one is refractoriness of chromium.

Moreover, $\mathrm{Cu}-\mathrm{Cr}$ materials have several very specificproperties, but inherentonly for this composition. Namely, it is a good heterogeneous property [6], low tendency to welding [2], high strength [7] etc. Each of these factors makes the $\mathrm{Cu}-\mathrm{Cr}$ composites the irreplaceable contact material in trolley wire [8], vacuum arc quenching chambers of middle/high power systems [2] or high-current vacuum circuit breakers [9].

On the other hand, it is obviously, that each field of application needs different material qualities. As a result, the various fabrication technologies as well as numerous stoichiometry of such composite are proposed nowadays.

For example, it was found in work [10], that $\mathrm{Cu}$ $45 \% \mathrm{Cr}$ material provides comparably the lowest cathode wear, while $\mathrm{Cu}-50 \% \mathrm{Cr}$ provides lowest anode wear. Moreover, it was concluded in [11] that it is much more difficultto form a melting pool on a $\mathrm{Cu}-\mathrm{Cr}$ contact surface with a higher proportion of chromium. On the other hand, an increasing of $\mathrm{Cr}$ content leads to decreasing of interruption rate [12].

As it can be concluded, a lot of different studies are devoted to comparison of various material ratios of composite $\mathrm{Cu}-\mathrm{Cr}$ contact materials with aim of improvement of resulting properties and its application optimization. However, the improving of this material performance is still the problem of great importance at the moment.

Our attention is focused on the influence of sintering temperature, as a parameter of fabrication technology, on erosion resistance of such electrodes under condition of thermal plasma. This topic has already been partially considered in our previous work [13]. Namely, it was shown that electrode materials, sintered at temperature $1050{ }^{\circ} \mathrm{C}$, have better erosion resistance in comparison with those, which were sintered at $750{ }^{\circ} \mathrm{C}$. But, it must be noted, the investigation of dependence of erosion resistance behaviour within the mentioned range of sintering temperature is not completed yet.

According to aforementioned, the aim of this work is more detailed investigation of the impact of sintering temperature on erosion resistanceof such composite materials under thermal action of plasma of electric arc discharge in steady-state mode at current of 3.5 A. Such study is provided in indirect manner by estimation of metal vapours content in midsection of discharge gap between $\mathrm{Cu}-\mathrm{Cr}$ composites electrodes, which were fabricated at sintering temperatures of $750,850,950$ or $1050{ }^{\circ} \mathrm{C}$.

\section{EXPERIMENT}

The electric arc discharges in steady-state mode at current of 3.5 A were studied in air atmosphere between vertically-oriented composite Cu35\%-Cr65\% electrodes. The electrodes` materials were fabricated by metal powder technology with pressuring and sintering at different temperatures. Thedischarge gap was $8 \mathrm{~mm}$ in all experiments

The component plasma compositions in the midsection of discharge gap were calculated in LTE 
assumption on the base of experimentally obtained by OES the radial distributions of plasma temperature and
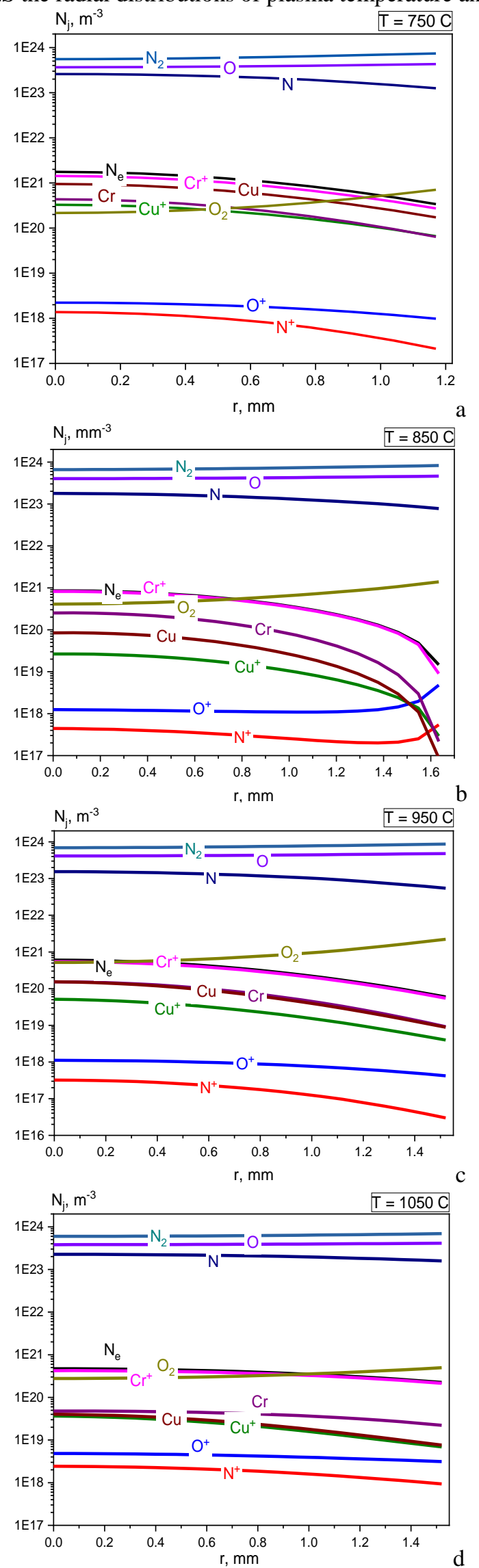

Fig. 1. The radial distributions of components composition of plasma of electric arc discharges in steady-state mode between composite $\mathrm{Cu}$-Cr electrodes, sintered at $750(a), 850(b), 950(c)$, and $1050^{\circ} \mathrm{C}(d)$ electron density. The experimental setup and algorithm of calculation are described in details in our previous works $[14,15]$.

\section{RESULTS AND DISCUSSION}

The radial distributions of plasma component compositions in midsection of discharge gap between $\mathrm{Cu}-\mathrm{Cr}$ composites electrodes, which were fabricated at sintering temperatures of $750,850,950$ or $1050{ }^{\circ} \mathrm{C}$ are shown in Fig. 1.

As it was mentioned above, the equilibrium assumption is used in the base of plasma composition calculation. Therefore, the physical solutions of analytical model $[14,15]$ in such calculations may indicate that the LTE can be realised in plasma channel of electric arc discharge between each type of composite electrodes.

It is clearly observed, that electrical conductivity of electric arc discharge plasma between all types of composite electrodes is provided predominantly by chromium due to its relatively low ionization energy in comparison with copper atom $(6.77$ and $7.74 \mathrm{eV}$, respectively). This conclusion is in a good agreementwith our results, obtained in the previous investigation [15].

Moreover, in spite of the fact, that chromium is refractory component, its concentration in midsection of discharge gap is higher than concentration of copper atoms. It can be explained by higher content of chromium component in initial composite material (Cu35\%-Cr65\%). This tendency is typical for discharge between all types of composites, besides electrodes, which was sintered at $750{ }^{\circ} \mathrm{C}$. Based on this, it can be assumed that increasing of sintering temperature leadsto decreasing of evaporation rate of copper as a component of composite materials.

The radial distributions of metal vapours content (copper and chromium) in plasma (Figs. 2-4) are calculated from corresponding component composition by equations:

$$
\begin{aligned}
X_{C u}, \%= & \left(N_{C u}+N_{C u}^{+}\right) \cdot 100 / \sum N_{j}, \\
X_{C r}, \%= & \left(N_{C r}+N_{C r}^{+}\right) \cdot 100 / \sum N_{j}, \\
& X_{\text {Metal }} \%=X_{C u}+X_{C r},
\end{aligned}
$$

where $N_{j}$ is a total particle concentration in the plasma of electric arc discharges in steady-state mode.

It can be concluded from the analysis of Fig. 2, that copper vapour content in discharge gap remainsinvariable within the accuracy of an experiment for electrodes, sintered at temperatures 850, 950, and $1050{ }^{\circ} \mathrm{C}$. At the same time the copper vapour content is noticeably higher in discharge gap between electrodes, sintered at $750{ }^{\circ} \mathrm{C}$, but is not exceed the chromium evaporation for this temperature. In contrast to this the essential sintering temperature dependence of chromium vapour contents is observed (see Fig. 3). 


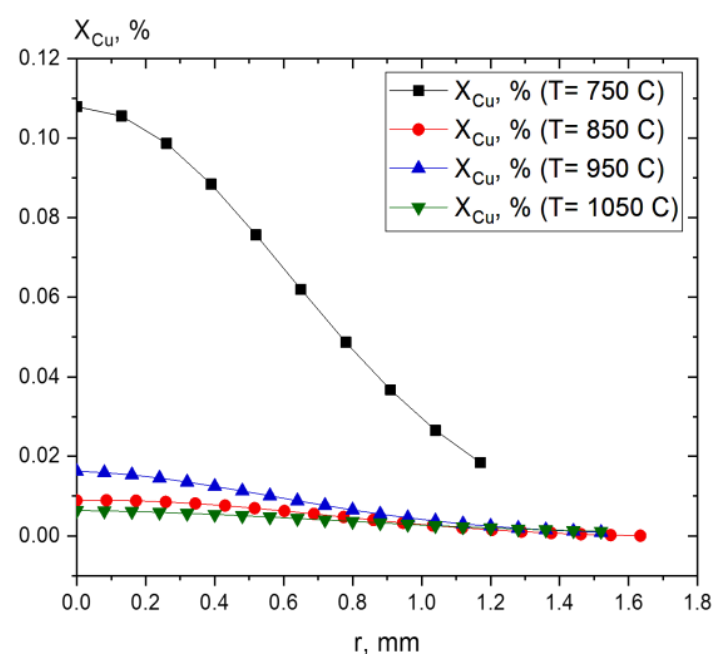

Fig. 2. The radial distributions of copper vapour content in plasma of electric arc dischargebetween

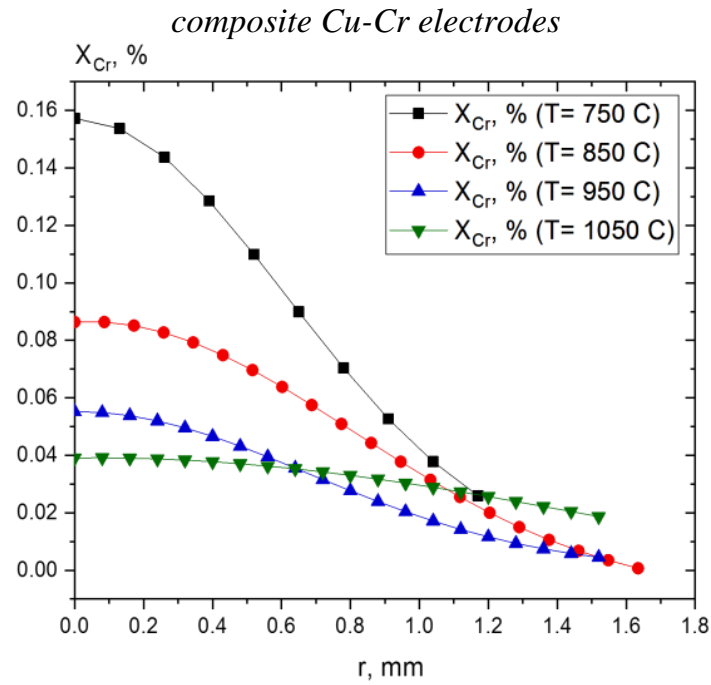

Fig. 3. The radial distributions of chromium vapour content in plasma of electric arc dischargebetween composite $\mathrm{Cu}$-Cr electrodes

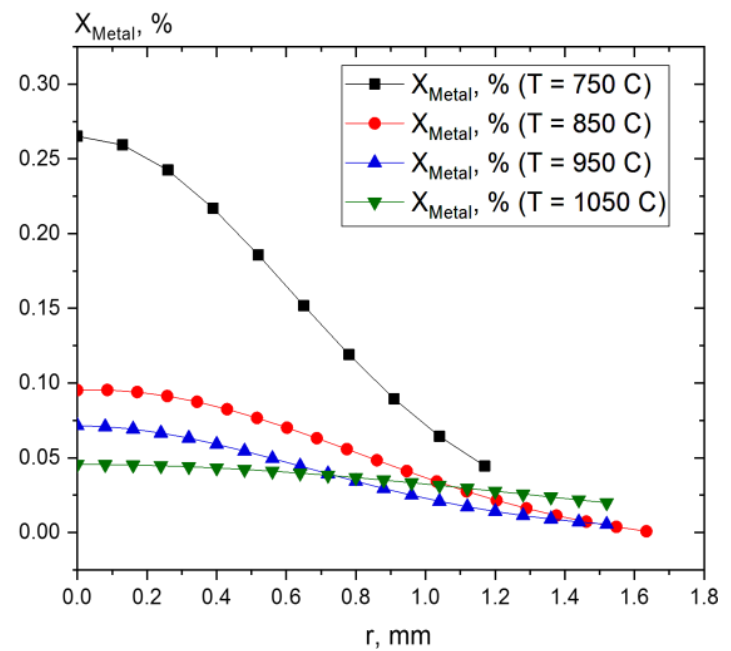

Fig. 4. The radial distributions of metal vapour content in plasma of electric arc dischargebetween composite $\mathrm{Cu}$-Cr electrodes

So, it can be concluded finally, that metal vapour content in plasma (see Fig. 4) and, in turn, erosion rate, is caused predominantly by evaporation of chromium component of $\mathrm{Cu}-\mathrm{Cr}$ composite electrodes.
Thus, it is found, that the content of metal vapour decreases with increasing of sintering temperatures, at which the composite $\mathrm{Cu}-\mathrm{Cr}$ materials were fabricated. It can be stressed, that the copper vapour content decreases with increasing of sintering temperature up to $850{ }^{\circ} \mathrm{C}$, after that it remains practically invariable. At the same time the tendency of the decreasing of chromium evaporation is still observed up to sintering temperature of $1050{ }^{\circ} \mathrm{C}$.

Finally, such comparison suggests that increasing of sintering temperatures positively impacts on erosion resistance of such composites under thermal action of plasma of electric arc discharge in steady-state mode at current of $3.5 \mathrm{~A}$.

It must be noted additionally, the methods, applied in this work, can be proposedforindirect investigation of materials erosion properties.

\section{CONCLUSIONS}

The plasma of electric arc discharges in steady-state mode between composite $\mathrm{Cu}-\mathrm{Cr}$ electrodes, manufactured at sintering temperatures of 750, 850, 950 or $1050{ }^{\circ} \mathrm{C}$, is investigated by OES. Namely the radial distributions of plasma components composition and corresponding radial distributions of metal vapour content in midsection of discharge gaps, are calculated on the base of experimentally obtained plasma temperatures and electron densities.

It was found, that the sintering temperatures impacts on erosion resistance of such composite materials under thermal action of plasma electric arc discharge in steady-state mode at current of $3.5 \mathrm{~A}$. It can be confirmed by decreasing of metal vapours contents in midsection of discharge gap with increasing of sintering temperature, at which composite electrodes` materials were fabricated.

\section{ACKNOWLEDGEMENTS}

This work was supported under joint project of research and technology collaboration No.8J19UA038 between Ukraine (No.M/1-2020) and Czech Republic (No.7AMB197UA).

\section{REFERENCES}

1. L.F. Nielsen. Composite Materials. Weinheim: «Wiley-VCH Verlag GmbH And Co. KGaA», 2006, 314 p.

2. P.G. Slade. Electrical contacts, principles and applications. CRC Press, 2014.

3. O. Gülcan, İ. Uslan, Y. Usta, C. Çoğun. Performance and surface alloying characteristics of $\mathrm{Cu}-\mathrm{Cr}$ and $\mathrm{Cu}$ Mo powder metal tool electrodes in electrical discharge machining // Machining Science and Technology. 2016, p. 523-546.

4. C. Mingrang, H. Yuefeng, C. Yilong, Y. Shengqiang. Mechanism and Experimental Research on Small-Hole EDM with $\mathrm{Cu}-\mathrm{Cr}$ Composite // Electrode. Sensors and Transducers. 2014, v. 174, p. 268-272. 
5. N.P. Wu. Electric Material Science. Beijing: «Mechanical Industry Press»,1993, p. 24-45

6. A. Papillon, J. Missiaen, J. Chaix, S. Roure, H. Schellekens. Sintering mechanisms of $\mathrm{Cu}-\mathrm{Cr}$ metallic composites // Int. Journal of Refractory Metals and Hard Materials. 2016, v. 65, p. 9-13.

7. L. Peng, X. Mao, K. Xu, W. Ding. Property and thermal stability of in situ composite $\mathrm{Cu}-\mathrm{Cr}$ alloy contact cable // Journal of Materials Processing Technology. 2005, v. 166, p. 193-198.

8. C. Masuda, Y. Tanaka. Fatigue properties of $\mathrm{Cu}-\mathrm{Cr}$ in situ composite // International Journal of Fatigue. 2006, v. 28, p. 1426-1434.

9. R. Muller. Arc-melted $\mathrm{Cu} \mathrm{Cr}$ alloys as contact materials for vacuum interrupters // Siemens Forsch.-u. Entwickl.-Ber. Bd. 1988, v. 17, p. 105-111.

10. I. Gershman, E. Gershman, A. Mironov, G. FoxRabinovich, S. Veldhuis. On Increased Arc Endurance of the Cu-Cr System Materials // Entropy. 2017, v. 19(8), p. 386-396.

11. Z. Wang, W. Yan, Y. Jiang, Y. Li, J. Liu, W. Wang, Y. Geng, J. Wang, Z. Liu, I. Sun. The Effect and Dynamic Behavior of Particles in High-Current Vacuum Arc Interruptions // J. Phys. D: Appl. Phys. 2018, v. 52(7), p. 1-20.
12. D. Heyn, M. Lindmayer, E.-D. Wilkening. Effect of Contact Material on the Extinctionof Vacuum Arcs Under Line Frequencyand High Frequency Conditions // IEEE Transactions on Components, Hybrids, and Manufacturing Technology. 1991, v. 14(1), p. 65-70.

13. A. Veklich, M. Kleshych, A. Murmantsev, S. Fesenko, V. Boretskij, O. Tolochyn. Spectroscopy of Thermal Plasma of Electric Arc Discharge between Consumable $\mathrm{Cu}-\mathrm{Cr}$ Composite Electrodes // XV Conference of Electronics and Applied Physics. 2019, p. 87-89.

14. I.L. Babich, V.F. Boretskij, A.N. Veklich, R.V. Semenyshyn. Spectroscopic data and Stark Broadening of $\mathrm{Cu}$ I and $\mathrm{Ag}$ I spectral lines: selection and analysis // Advances in Space Research. 2014, v. 54, p. 1254-1263.

15. A. Veklich, V. Boretskij, M. Kleshych, S. Fesenko, A. Murmantsev, A. Ivanisik, O. Khomenko, O. Tolochyn, M. Bartlova. Thermal plasma of electric arc discharge between $\mathrm{Cu}-\mathrm{Cr}$ composite electrodes // 23rd Symposium on Physics of Switching Arc. 2019, v. 6(1), p. 27-30 doi:10.14311/ppt.2019.1.27.

Article received 05.01.2021

\title{
ТЕРМИЧЕСКОЕ ВЛИЯНИЕ ПЛАЗМЫ ЭЛЕКТРОДУГОВОГО РАЗРЯДА НА КОМПОЗИТНЫЕ Си-Сr-МАТЕРИАЛЫ
}

\author{
А. Мурманцев, А. Веклич, В. Борецкий, М. Бартлова, Л. Достал, Джс. Пишка, Д. Шимек, А. Толочин
}

Представлены результаты исследования плазмы дуговых разрядов в установившемся режиме методами оптической эмиссионной спектроскопии (ОЭС) между электродами из $\mathrm{Cu}-\mathrm{Cr}$-композитных материалов, изготовленных при различных температурах спекания: 750, 850, 950 и $1050{ }^{\circ} \mathrm{C}$. В частности, на основе анализа параметров плазмы исследовано влияние температуры спекания на эрозионную стойкость таких композиционных материалов, которая определялась косвенным способом - путем оценки содержания паров металлов в среднем сечении разрядных промежутков между электродами. Распределения содержания паров металлов были рассчитаны в предположении локального термодинамического равновесия на основе экспериментально полученных радиальных распределений температуры плазмы и электронной концентрации.

\section{ТЕРМІЧНИЙ ВПЛИВ ПЛАЗМИ ЕЛЕКТРОДУГОВОГО РОЗРЯДУ НА КОМПОЗИТНІ Си-С-МАТЕРІАЛИ}

\section{О. Мурманцев, А. Веклич, В. Борецький, М. Бартлова, Л. Достал, Дюс. Піика, Д. Шимек, О. Толочин}

Представлено результати дослідження плазми дугових розрядів у стаціонарному режимі методами оптичної емісійної спектроскопії (OЕC) між електродами з $\mathrm{Cu}-\mathrm{Cr}$-композитних матеріалів, виготовлених при різних температурах спікання: $750,850,950$ та $1050^{\circ} \mathrm{C}$. Зокрема, на основі аналізу параметрів плазми досліджено вплив температури спікання на ерозійну стійкість таких композиційних матеріалів, яка визначалась у непрямий спосіб - шляхом оцінки вмісту парів металів у середньому перерізі розрядних проміжків між електродами. Розподіли вмісту парів металів були розраховані в припущенні локальної термодинамічної рівноваги на основі експериментально одержаних радіальних розподілів температури плазми і електронної концентрації. 